eCommons@AKU

\title{
Transforming classroom discourse and pedagogy in rural zimbabwe classrooms: the place of local culture and mother tongue use
}

Jacob Marriote Ngwaru

Aga Khan University, marriote.ngwaru@aku.edu

Follow this and additional works at: http://ecommons.aku.edu/eastafrica_ied

Part of the Elementary and Middle and Secondary Education Administration Commons, and the Elementary Education and Teaching Commons

\section{Recommended Citation}

Ngwaru, J. M. (2011). Transforming classroom discourse and pedagogy in rural zimbabwe classrooms: the place of local culture and mother tongue use. Language, Culture and Curriculum, 24(3), 221-240.

Available at: http://ecommons.aku.edu/eastafrica_ied/19 


\section{Language, Culture and Curriculum}

\section{Transforming classroom discourse and pedagogy in rural Zimbabwe classrooms: the place of local culture and mother tongue use}

\section{Jacob Marriote Ngwaru}

To cite this article: Jacob Marriote Ngwaru (2011) Transforming classroom discourse and pedagogy in rural Zimbabwe classrooms: the place of local culture and mother tongue use, Language, Culture and Curriculum, 24:3, 221-240, DOI: 10.1080/07908318.2011.609624

To link to this article: http://dx.doi.org/10.1080/07908318.2011.609624

曲 Published online: 01 Nov 2011.

Submit your article to this journal $\widetilde{ }$

Џلll Article views: 406

Q View related articles $\sqsubset$

Citing articles: 2 View citing articles $\square$ 


\title{
Transforming classroom discourse and pedagogy in rural Zimbabwe classrooms: the place of local culture and mother tongue use
}

\author{
Jacob Marriote Ngwaru* \\ National Centre for Language and Literacy, University of Reading, Reading, UK
}

(Received 2 March 2010; final version received 10 July 2011)

\begin{abstract}
Rural African classrooms are still practising discourses and pedagogies that contribute towards students' continued underachievement and marginalisation. The use of behaviourist-based pedagogical approaches and the exclusion of learners' sociocultural experiences including their mother tongue (MT) still characterise most classroom practices. The use of classroom discourse that severely constrains opportunities for pupil participation and the development of higher order thinking skills has also been noted. This paper describes an intervention based on the principles of transformative and constructive developmental pedagogy designed to improve approaches to teaching and learning in a primary school in rural Zimbabwe. Examples of prevailing classroom practices organised on prescriptive behaviourist procedures serve as the backdrop to a description of the intervention. In a meeting negotiated with teachers at the outset of the project, feedback based on classroom observation was offered to the teachers and alternative approaches were suggested. The latter focussed particularly on taking account of the local culture and pupils' own experiences and on the use of the MT. Examples of teachers embracing this approach are presented and the implications for the professional development of teachers are outlined.
\end{abstract}

Keywords: literacy and socio-cultural experiences; classroom discourse; critical pedagogy; funds of knowledge

\section{Introduction}

Currently, research acknowledges that family literacy practices and pupils' funds of knowledge play a unique role in the way individuals learn everyday practices (Gonzalez et al., 1993; Greenberg, 1989; Moll, Amanti, Neff, \& González, 1992; Moll et al., 1990; Velez-Ibanez, 1989). The role of the teacher as an agent of socialisation has also been highlighted (Fillmore \& Snow, 2000). This justifies the need for the continual appraisal of African classroom pedagogies to assess the extent to which children's socio-cultural practices are recognised and utilised. The constructs underpinning most curricula in Africa, however, are reminiscent in some respects of the first formal school in Africa south of the Sahara, in South Africa, about 350 years ago in 1658. The first curriculum (rigidly prescriptive, behaviourist, and structuralist) had:

*Email: mngwaru@yahoo.com 
the task of giving them instruction in the morning and afternoon ... To encourage the slaves to attend and to hear or learn the Christian prayers ... and subject those people to proper discipline. (Molteno, 1984, p. 49)

In the West, this approach has systematically given way to the realisation that classroom practice can be based on post-modernist and constructivist constructs. They can be developed, transformed, and enriched by drawing upon (children's) existing funds of knowledge (Gonzalez et al., 1993; Gonzalez, Moll, \& Amanti, 2005).

\section{Funds of knowledge and literacy learning}

Dei and Asgharzadeh (2005) indicated that post-colonial educational policies and practices (curriculum, texts, and pedagogies) in Africa fail to adequately acknowledge and respond to the variety of human experiences. They often exclude cultural resources and children's funds of knowledge from classroom work. This knowledge is broad and diverse and includes information about farming, animal rearing, traditional medicine, trading, folk stories and folklore, norms and values and moral knowledge, carpentry, masonry, language and communication skills, and a host of many others (Gonzalez et al., 2005; Moll et al., 1992). These are historically accumulated and culturally developed bodies of knowledge and skills essential for households' or individuals' functioning and well-being. Cummins and Sayers (1995, p. 75) corroborated the view that: "prior experience provides the foundation for interpreting new information. No learner is a blank slate. In reading for example, we construct meaning by bringing our prior knowledge of language and of the world to the text'. In collaborative studies, Gonzalez et al. (2005) made findings that challenge the status quo by asserting that local knowledge has a legitimate place in formal education, a view that has consistently been stressed by some educationists, academics, researchers, and advocates of mother tongue (MT)/bilingual education (Bloch, 2005; Brock-Utne, 2001; Brock-Utne \& Alidou, 2005; Brock-Utne \& Hopson, 2005; Cummins, 1986; Edwards, 1998).

Bourdieu (1991) asserted that educational success entails a whole range of cultural behaviour, including non-academic features such as gait or accent. Lankshear, Gee, Knobel, and Searle (1997, p. 3) said that (now) the inherently social character and embeddedness of reading and writing in larger social practices assume greater theoretical importance than ever before. Literacy studies now privilege meaning over mechanical skills, with meaning being seen much more in terms of socio-cultural processes than in terms of private internal cognitive states.

\section{Language and literacy in African classrooms}

The application of theories of language, power, and critical pedagogy to African classrooms has been relatively limited. There are nonetheless a growing number of studies which demonstrate an awareness of a range of obstacles to learning, including the use of a second language as the medium of instruction and the use of inappropriate pedagogy. Most studies of literacy in African classrooms focus on issues created by the use of unfamiliar languages in which both children and teachers have limited competence. This situation is not, of course, unique to Africa - Skutnabb-Kangas (1981) has commented at length on the stress experienced by both pupils and teachers working through the medium of an unfamiliar language. These challenges are, however, particularly acute in African settings where, for the vast majority of the population, the colonial language has to be learned anew by each generation. 
Writers such as Scheerens (2000) and Verspoor (2003) suggested that the policy of using English appears to have a major impact on the discursive patterns found in many of the classrooms. Probyn's (2001) studies of the perceptions and practice of teachers teaching through the medium of English in township schools in South Africa suggest that teachers and students experience stress in teaching and learning through medium of a language in which they are not able to communicate freely. This has negative consequences for learning including lack of self-confidence, disaffection, and alienation. Practices in these classrooms are dominated by routines, choral responses, and code switching, which have been described by Chick (1996) and Hornberger and Chick (2001) as 'safe talk'. Most commentators who focus upon teacher-led safe talk see it as basically a negative procedure that constrains classroom learning. Hornberger and Chick (2001) presented ethnographic studies of language practices in two classrooms, one in South Africa where Zulu-speaking students are taught through English and the other in Peru where Quechua-speaking students are taught through Spanish. In both cases, the language of instruction is imperfectly understood by many students and even by some of the teachers. As a result, interaction in these classrooms was limited to mere repetition, cued responses, and chorus-like answers. Writing consisted mostly of copying from the board. Hornberger and Chick analysed these practices as safe talk, which they defined as a form of classroom interaction that allows a minimal kind of participation without loss of face for the students and (especially) the teacher. They noted that safe talk practices do not contribute to student emancipation but to the continuing marginalisation of the language minority students and their communities.

Safe talk 'creates a space where the students know more or less what to expect and how to behave in class', but where a high price is paid in terms of (a lack of) learning. These observations were confirmed by similar studies by Brock-Utne and Alidou (2005) on Tanzania and South Africa and Williams and Snipper (1990) on Malawi and Zambia. Gutierrez, Larson, and Kreuter (1995, p. 449) referred to such practices as the 'teacher script', which they defined as: 'an orientation that members come to expect after repeated interactions in contexts constructed both locally and over time'. Abd-Kadir and Hardman (2007) explored the discourse of whole class teaching in Kenyan and Nigerian primary school English lessons using a system of discourse analysis focussing on the teacher-led three-part exchange sequence of initiation-response-feedback (IRF). The focus of the analysis was on the first and third parts of the IRF sequence as it is here that research suggests that teachers can enhance pupil learning through questions and follow-up which ask pupils to expand on their thinking, justify or clarify their opinions, or make connections to their own experiences. The findings suggest that teacher questions were mainly closed, requiring recall of information. Teacher follow-up, where it occurred, often consisted of a low-level evaluation of pupil response, thereby severely constraining opportunities for pupil participation and higher order thinking skills.

\section{Critical pedagogy}

Critical pedagogy was heavily influenced by the works of Freire $(1995,2006)$, who heavily endorsed students' ability to think critically about their education situation, a way of thinking that allows them to, 'recognise connections between their individual problems and experiences and the social contexts in which they are embedded'. Critical pedagogy is, therefore, a teaching approach that attempts to help students question and challenge domination and the beliefs and practices that dominate. In other words, it is a theory and practice of helping students achieve critical consciousness. Shor (1992, p. 129) defined critical pedagogy as: 
Habits of thought, reading, writing, and speaking which go beneath surface meaning, first impressions, dominant myths, official pronouncements, traditional clichés, received wisdom, and mere opinions, to understand the deep meaning, root causes, social context, ideology, and personal consequences of any action, event, object, process, organization, experience, text, subject matter, policy, mass media, or discourse.

Unlike traditional perspectives of education that claim to be neutral and apolitical, critical pedagogy views all education theories as intimately linked to ideologies and shaped by power, politics, history, and culture. Given this view, schooling functions as a terrain of ongoing struggle over what will be accepted as legitimate knowledge and culture. In accordance with this notion, a critical pedagogy must seriously address the concept of cultural politics by both legitimising and challenging cultural experiences that comprise the histories and social realities that, in turn, comprise the forms and boundaries that give meaning to students' lives (Darder, 1991, p. 77, cited in Darder, 1995).

In South Africa, Newfield and Stein (2000) reported a study of critical pedagogy in opposition to the status quo, an attempt to overthrow the legacy of apartheid in South African classrooms. At the outset, classrooms seemed rigid, prescriptive places of exclusion, repression, and lack of independent thinking and creativity - qualities inconsistent with the political ideals of the new South African state. They also seemed to be inspired and assisted by the notion of multiliteracies (New London Group, 1996), which argues that the multiplicity of communication channels and increasing cultural and linguistic diversity in the world today call for a much broader view of literacy than portrayed by traditional language-based approaches. Newfield and Stein tried to engage with pedagogical conditions of prescription, rote learning, and lack of equity. They concluded that when issues of culture and identity are addressed, self-esteem, confidence, and respect for others develop and creativity burgeons.

In Zimbabwe, there are few reported studies of literacy practices. There has been, however, the Zimbabwe Literacy Norms Project (University of Zimbabwe, 2002), part of a series of projects aimed at delivering Quality Education for Social Transformation (QUEST) for the Africa Region (Uganda, Kenya, and Zimbabwe). The Literacy Norms Project considers the effects of learning a second language, particularly a colonial language that is always 'laden with extra baggage' (University of Zimbabwe, 2002, p. 3), the issue of the interaction between L1 and L2, the relationship that exists and/or that should exist between L1 and L2, more so when the L2 is a colonial language, etc.

This paper reports some of the research findings based on a rural primary school in Zimbabwe. Observations were to establish the extent to which children's funds of knowledge were integrated in the school literacy practices, the factors underlying pedagogical practice, and how approaches to literacy and schooling could become more constructivist and interactionist.

\section{Exploring classroom practices}

I carried out this study as a critical ethnographer (Carspecken \& Apple, 1992) and native researcher involved in auto-ethnography (Agar, 1996; Berger, 2001; Ellis \& Bochner, 2000; Reed-Danahay, 1997). My aims were to document and report the situation of the participants and empower them by including an advocacy perspective (Carspecken, 1995; Carspecken \& Apple, 1992; Thomas, 1993). Critical ethnographers are, typically, politically minded individuals who seek, through their research, to challenge inequality and domination (Carspecken \& Apple, 1992). As a critical native ethnographer, I used 
this study to underpin my desire to 'liberate' my participants; 'critical ethnographers use their work to aid emancipatory goals or to negate the repressive influences that lead to unnecessary social domination of all groups' (Thomas, 1993, p. 4). My intent was to empower the research participants by including an advocacy perspective including catalytic validity. Catalytic validity requires that the documentation of the research topic should lead to a greater awareness and, where possible, the increased participation of informants. With catalytic validity, 'an ideal audience is in a position to use ethnographic work as a resource, critically appropriating aspects of the work for their ability to clarify the basis of everyday life and the possibilities for its transformation' (Simon \& Dippo, 1986, p. 199).

Lather (1986a, 1986b) explained 'catalytic validity' as a measure of validity in critical research:

Catalytic validity represents the degree to which the research process reorients, focuses, and energizes participants toward knowing reality in order to transform it ... Efforts to produce social knowledge that will advance the struggle for a more equitable world must pursue rigor as well as relevance. (Lather, 1986b, p. 272)

\section{The present classroom observation study}

NB. All names of places, teachers, and pupils are pseudonyms (except where specifically stated to the contrary).

\section{The school: Chitubu Primary School and the community}

Chitubu Primary School is in the southern province of Zimbabwe, about $70 \mathrm{~km}$ from the provincial capital, where the home language is ChiShona, spoken by about $85 \%$ of the Zimbabwe population. It is situated along one of the main district roads linking the district capital to the motorway linking the provincial capital and the capital city. At the time of the study, it had a pupil enrolment of 213 from Grades 1 to 7 , five qualified teachers, and four student teachers as well as a pre-school class (Grade 0). The school serves an area of up to eight resettlement villages with some of the pupils walking $10 \mathrm{~km}$ each day. The school worked closely with the Parents Teacher Committee on matters of governance and was based on a system of co-operative administration with the Head, the Deputy Head, and the senior teacher working as the management team and other teachers allocated separate responsibilities. I originally come from the same district in which the school is located and was generally familiar with both the socio-economic and political milieu of the stakeholders.

\section{Lesson observations}

Over a period of three months, I observed and recorded a total of 34 lessons from Grades 1 to 7 in detailed field notes after spending the first two weeks observing without recording to minimise observer effect. A total of five lessons from detailed field notes are presented and discussed to highlight the nature of the prevalent pedagogy. The first three lessons from experienced qualified teachers are taken from lessons before the intervention for advocacy and catalytic validity. The last two are taken from lessons by student teachers taught after the intervention. All three lessons presented here are focussed on language structure because I was looking at the teaching of English in ESL contexts in rural areas. For rural children in Zimbabwe, English is a language that they first meet when they go to pre-school or 
formal school. It is not used at all outside these formal contexts to the extent that it is basically a foreign language serving no other purpose than being used in the school and ultimately becoming the language of education. I believed that in 'language structures' lessons, teachers had the opportunity to demonstrate their own grasp of language content and methodology.

\section{Transcription conventions in reporting classroom interactions}

Classroom observations were a central part of my critical ethnography with the goal of answering questions about how classroom teachers promoted connections between home and school lives, how children made use of their home lives in the context of the school, and how the teachers promoted a supportive literate community. Classroom proceedings were recorded in detailed field notes after it proved difficult to use a camcorder, iPod, or an ordinary audio-cassette recorder to record the whole classroom situation. I used shorthand notes first and transcribed the notes immediately after the lesson. I showed the transcribed lesson script to the teacher for comments and approval. The teacher edited and certified the scripts before I could use them.

Within the situated methodology approach, I used the critical literacy framework to analyse the meanings being generated and shared in the classrooms. I positioned myself as a classroom discourse analyst giving meaning to what was going on in the classrooms. If I had been observing classroom activities a decade or so ago, I would have been looking at how children learnt how to read and write using the notions of reading and writing perceived as specific cognitive abilities or sets of skills. The inherently social character and embeddedness of reading and writing in larger social practices now assume greater theoretical importance (Lankshear et al., 1997, p. 3). Lesson observations offered opportunities to validate the extent to which pedagogy in the primary school was structured to empower the child. It is the extent to which lessons reflected the conception of literacy as social practice that I was most interested in because teaching ESL in the literacy framework is most critical and empowering.

There are eight lessons taught per day per class, and since I did not want to cause much disruption to the smooth running of the school, I observed a limited number each day. Out of the nine days of observation, I observed three lessons per day on days 1, 4, 5, 6, and 7; two lessons on day 2; and four lessons on day 3. Four lessons were observed in each class from Grades 1 to 6 and three lessons in Grade 7 (Grade 7s are usually preparing for their national external examinations and prefer less interference). At the end of the four-week observation period, some 27 30-min lessons had been observed as indicated in Table 1, and the transcript convention used is detailed below the schedule.

Table 1. Lesson observation schedule set out according to grade and date.

\begin{tabular}{lcccccccccc}
\hline Days $\rightarrow$ & 1 & 2 & 3 & 4 & 5 & 6 & 7 & 8 & 9 & \\
Dates $\rightarrow$ & 14 & 15 & 23 & 27 & 28 & 29 & 05 & 06 & 07 & \\
& June & June & June & June & June & June & July & July & July & \\
Grades $\downarrow$ & & & & & & & & & & Total \\
1 & & & $\bullet$ & & $\bullet$ & & $\bullet$ & $\bullet$ & $\bullet$ & 4 \\
2 & & & $\bullet$ & & $\bullet$ & & $\bullet$ & & & 4 \\
3 & & $\bullet$ & $\bullet$ & $\bullet$ & & $\bullet$ & & & $\bullet$ & 4 \\
4 & $\bullet$ & & & $\bullet$ & - & $\bullet$ & & & $\bullet$ & 4 \\
5 & $\bullet$ & & $\bullet$ & $\bullet$ & $\bullet$ & & & & & 4 \\
6 & & $\bullet$ & & & & $\bullet$ & & $\bullet$ & & 3 \\
7
\end{tabular}




\section{Transcript conventions}

The following conventions have been adopted to represent the classroom interactional activities:

$\begin{array}{ll}01,02 & \text { speaker turn } \\ \mathrm{T} & \text { teacher } \\ \mathrm{Ma}, \mathrm{Ko} & \text { initial letters of pupil's name } \\ \mathrm{P} 1, \mathrm{P} 2 & \text { unknown pupils } \\ \mathrm{Pp} & \text { more than one pupil speaking } \\ \text { ] } & \text { overlapping speech } \\ \text { Bold } & \text { emphasis given by speaker } \\ (\mathrm{x} \mathrm{x} \mathrm{x}) & \text { unintelligible speech } \\ <> & \text { explanatory or interpretive comment by the author } \\ \text { italics } & \text { translation of original speech in MT }\end{array}$

My focus during observation was on lesson objectives, lesson development steps, pupil activities, and pupils' written work. The most important issue at every stage of the lesson observation was the integration of children's socio-cultural experiences, and I also paid attention to teachers' language to identify the affective socio-cultural meanings influencing their interaction with the children.

\section{Extracts from transcripts of lessons}

\section{Extract 1:}

This extract is a Grade 3 (8-9-year-olds) lesson taught by the experienced teacher Ms Waambo.

T: Let us all start with the song about food.

Pp: Food is good, good, good

We all love food, food, food

Food is good, good, good

T: What food do you like?

P1: I like beans,

P2: I like rice,

P3: I like bread,

P4: I like bananas ...

T: Now I want you in your groups to practice the structure 'I like ...'

$<$ In their groups, children take turns to say what foods they like best, and after a while they report to class $>$ :

P1: I like meat

P2: I like eggs

P3: I like eggs

P4: I like bananas

P5: I like fish

P6: I like bananas

P7: I like sadza

P8: I like groundnuts

P9: I like porridge

T: Now I want you to talk about people you like: Who do you like? I want you to ask each other the question, 'Who do you like?' 
$<$ Pupils ask each other the question 'Who do you like?', and answer, naming their relatives, as if reciting $>$.

P1: I like my father

P2: I like my mother

P3: I like my sister; I like my brother; I like my aunt

T: You can also talk about teachers you like: which teachers do you like? ...

$<$ Pupils take turns to recite using the structure 'I like ...' and name teachers in the school at random $>$.

T: OK. In your exercise books I want you to write five sentences.

$<$ Teacher made use of the chalk board and the textbook only $>$.

This is an example of a traditional structuralist, behaviourist, and product-based lesson. The regurgitation of the language item is considered to be equivalent to learning. The language structure 'I like ...' is taught in abstraction, with the learners' socio-cultural context removed. No opportunities are created for pupils to construct new knowledge from their environment and relate it to the target language structure through culturally embedded questions, discussions, or extensions - regarding, for example, why a given food stuff, person, or teacher was liked or preferred to the other. The food stuffs, meat, eggs, fish, and bananas referred to are more common in the learners' textbooks than in their homes. The teacher could have promoted children's real experiences by asking them about the foods that were common in their homes. The potential of such a relevant and socially constituted topic - liking food, people, and teachers - was completely ignored or overlooked, and the lesson remained a decontextualised language-structure activity (see 'teacher script': Gutierrez et al., 1995).

My interpretation is that the teacher's difficulties may arise in part from a lack of L2 competence. This is likely to make her keep to a teacher script and fail to adopt more constructivist and interactionist approaches that have the potential to enhance pupil learning through questions and follow-up activities. It is through such activities that pupils expand on their thinking, justify or clarify their opinions, or make connections to their own experiences (Abd-Kadir \& Hardman, 2007). Willis (1995, p. 34) has argued that children from linguistic or cultural minority groups continue to have difficulty in achieving school success because the dominant pedagogical approaches are based on: 'a narrow understanding of school knowledge and literacy, which are defined and defended as what one needs to know and how one needs to know to be successful in school and society'.

There was little demonstration in the case just cited of an understanding that literacy is socially constituted - since teaching is situated in schools and communities - or an appreciation of the crucial influence of the social, cultural, and historical contexts of schooling on teaching and learning (Bennett, 1999; Irvine \& Armento, 2000). In this lesson, school knowledge in the form of a single language structure overshadows real, socially constituted knowledge that includes pupils' existing funds of experience and ways of knowing. Sadly, the learning experience remains outside the pupils' social reality and practically excludes the literacy and social practices they have acquired in life. School literacy taught this way remains an alienating experience (Gee, 1996). 


\section{Extract 2:}

This extract is from a Grade 6 (11-12-year-olds) lesson taught by Mrs Mazhambe. This is another 'language structures' lesson that involves changing sentences from direct to indirect speech. Six sentences formed the basis of the exercise and the lesson begins with a jingle that takes less than 2 min.

$\mathrm{T}$ : Today we want to change direct sentences to indirect sentences. Look at the sentences on the board, and someone to read them out for us.

T: Patsva, please stand up and read out the sentences on the board.

Pa: 'Chipo ate rice and chicken yesterday', said her mother.

'Your teacher has gone for a funeral', the head teacher told us.

Ruva said: 'Ms Maziofa went to Masvingo on Friday'.

'Stop making noise', the prefect told us.

'Today the weather is cold', said Gilbert.

'I will go to Gweru on Friday', Esther told me.

T: Let us do the first one together. Tabitha please can you do the first one?

Ta: Her mother said Chipo ate rice and chicken yesterday.

T: Yes but you should add 'that' to read ...

$<$ Teacher writes on the board: 'Her mother said that Chipo ate rice and chicken yesterday'. $>$

T: In your groups now I want you to change the rest into indirect speech.

$<$ Pupils go into groups and begin to talk in low voices. $>$

T: Now let us see what you have done.

$<$ Pupils try to follow the example given by the teacher, starting with the end of the sentence and adding 'that' as given, producing the following sentences that the teacher wrote on the board: $>$

P1: Her mother said that Chipo ate rice and chicken yesterday

P2: The head teacher told us that your teacher has gone for a funeral

P3: Ruva said that Ms Maziofa went to Masvingo on Friday

P4: Stop making noise the prefect told us that

P5: Gilbert said that today the weather is cold.

P6: I will go to Gweru on Friday Esther told me that.

T: Sentences 4 and 6 need corrections: 'that' should not come at the end of sentence.

$<$ Before pupils had said anything, the teacher wrote the following sentences that she said were correct:

'The prefect told us that stop making noise.

Esther told me that I will go to Gweru on Friday'. >

T: Write these sentences in your exercise books.

This is another typical, traditional structural grammar lesson, with very little bearing on constructivist learning. In this lesson, syntactical mechanical skills are treated as the essence of language structures. Even though this is a Grade 6 lesson, the preoccupation is with the 
structure of a sentence and not with the semantic or social meaning it conveys. The teacher's emphasis is on getting the children to arrange words in a certain order rather than to make different meanings using the same set of words. Leaving aside the fact that the indirect sentences accepted as correct are in fact incorrect, the teacher fails to use more constructivist approaches to integrate pupils' funds of knowledge into the pedagogy. The lesson ultimately only focusses on arranging words to change sentences from the direct to the indirect form.

As in Hornberger and Chick's (2001) study, interaction in these Zimbabwe classrooms was limited to mere repetition, cued responses, and chorus-like answers. Writing consisted mostly of copying from the board. Again, the food referred to, rice and chicken, was not part of pupils' everyday diet. And journeys to town were not usual for pupils who were more likely to be visiting relatives in rural areas. Common socio-cultural experiences are presented largely as grammatical structures that do not relate to real experiences. Reference to real experiences could have called for more culturally embedded questions, discussions, or extensions regarding topical and cultural issues. The teacher's classroom is not a dynamic interactional space where individuals come together for purposes of schooling to construct situated definitions of teacher and student knowledge, values, and so on (Au, 1993, p. 9). Much of the conventional instruction here reflects a tacit conception of the teaching/learning process that might be termed the transmission model. The essence of this model is that the teacher's role is seen as preparing and transmitting information to learners. The learners' role is to receive, store, and act upon this information (Tishman, Jay, \& Perkins, 1992, p. 157). In this extract, the culture of the classroom is not a dynamic system of values, beliefs, and standards, developed through understandings that the teacher and the students have come to share (Au, 1993).

\section{Extract 3:}

This extract comes from a Grade 7 (12-13-year-olds) lesson taught by an experienced teacher, and Deputy Head Teacher, Mr Mazhambe. The topic is the prepositions 'between' and 'among'. The materials used consist of small pebbles.

T: Can two pupils come to the front; any volunteers?

$<$ Two boys volunteer and walk up to the front. $>$

T: Can someone come and share these stones between the two boys?

$<$ Simba comes to the front and shares the pebbles between the two boys. Teacher writes the following sentence on the board: 'Simba shares the stones between two boys'. $>$

T: Can three pupils come up the front?

$<$ Three boys again volunteer. $>$

T: Someone to come and share the stones among these boys.

$<$ Rosemary goes to the front and shares the pebbles among the three boys. Teacher writes on the board: 'Rosemary shared the stones among three boys'. Teacher repeats the first sentence on the board: $>$ 
T: Simba shared the stones between two boys.

T: Any five pupils to come up front?

$<$ Five boys volunteer. $>$

T: Anyone to share these ten books among these boys?

$<$ Shepherd volunteers and shares the ten books among the five boys and teacher writes the following sentence on the board: 'Shepherd shared ten books among the five boys'.>

T: What have you noticed about the use of the two prepositions?

$<$ All pupils remain quiet (safe talk) and teacher goes on: $>$

T: Please make sentences of your own using 'between' and 'among'.

$<$ Pupils remain quiet and teacher calls out names at random $>$ :

T: Sharai?

Sh: Shadreck is sitting between Tabeth and Tapera.

$\mathrm{T}$ : Another trial: Tabeth.

Ta: The flag pole is standing between the two boys.

T: Do you not see that they are different from what we did together?

T: Tapera?

Ta: There was an accident between the car and the train.

$<$ Teacher struggles to refuse Tapera's sentence and draws a car parked between two trees and says: 'It is not the same'. Teacher cannot say anything further about this and continues: $>$

T: Let's move on to 'among': Tinaye?

Ti: Among the pupils in the classroom, one of them was ill.

T: What about Chipo? Use 'among' in a sentence as we did above.

Ch: Among Shadreck, Tapera and Robert, one of them is in Grade 6.

$<$ The teacher shows that he does not accept Chipo's sentence, but fails to say anything more about the sentences and moves on: $>$

T: Open your English textbooks on page 53 and read the first two sentences from the book.

$<$ Pupils within the clusters of children that share a single textbook read aloud the sentences. $>$.

P1: She shared the apples between two boys.

P2: She shared the apples among three boys.

T: In your groups, please write your own sentences in your exercise books - one using 'between' and another using 'among'.

$<$ In their groups, pupils write the following sentences in their exercise books: 
P1: Rosemary is sitting between two boys.

P2: Mary is sitting between trees.

P3: My mother shared apples among the girls.

P4: Among three boys is one of them.

P: Makanda shared 5 oranges among them. $>$

T: OK close your books it is ten o'clock. It is break time.

The focus of this lesson was a grammatically dated distinction between the prepositional structures 'among' and 'between'. This illustrates the difficulties ESL teachers encounter as a result of their pedantic understanding of the language. Equivalents of the prepositional structures 'between' (two) and 'among' (more than two) do not exist separately in the children's home language and culture. The teacher could have taken account of this and started by acknowledging this fundamental difference between the children's L1 and the L2. It was not surprising that the pupils failed completely to use these words in the context of sharing as planned for in the lesson. Instead, all the examples provided were to do with location and not with sharing at all. Putting to one side again for a moment the issue that this distinction does not reflect modern, educated usage, the teacher clearly did not have the capacity to explain what he wanted. The teacher's approach, it could be argued, lacked critical pedagogical awareness. He appeared to dwell on the limited technical use of the two prepositions as legitimate knowledge in this context, despite the fact that that difference did not even occur in the children's language and culture.

Critical pedagogy views all education theories as intimately linked to ideologies shaped by power, politics, history, and culture, where schooling functions as a terrain of ongoing struggle over what will be accepted as legitimate knowledge and culture (Darder 1991, p. 77, cited in Darder, 1995). Devoting a whole lesson to trying so hard to teach just the difference between two words suggests a political defeat for the teacher and a missed opportunity for the pupils because they cannot hope to be liberated by literacy. As Freire (1985) postulated, when we try to be neutral we support the dominant ideology because education must be either liberating or domesticating. Teachers, then, must recognise themselves as politicians, helping students believe in themselves by valuing and validating their cultural experiences. Teachers must communicate more effectively, and with the help of the pupils' L1, in order to utilise experiences that are socially constituted. In this lesson, safe talk and the transmission model approach were twin barriers to successful pedagogy.

These lessons illustrate that pedagogy in rural African schools has not changed much over time and is still highly prescriptive, behaviourist, and transmissional. Just as Newfield and Stein (2000) observed in their study in South Africa, the present Zimbabwe classrooms also seem to be rigid, prescriptive places of exclusion, repression, lack of independent thinking, and lack of creativity. Here existed a situation that also calls for inspiration from the notion of multiliteracies (New London Group, 1996) to engage with pedagogical conditions of prescription, rote learning, and lack of equity. A new culture of learning needs to be established. Issues of culture and identity need to be addressed, so that self-esteem, confidence, and respect for self and others can develop (Gbado, 2008) and pedagogical creativity can be released.

\section{Intervention to promote catalytic validity}

In pursuit of catalytic validity, I then set out to intervene. Having observed about 20 lessons, I had a meeting with all teachers. In general terms, the intervention can be seen as an example of critical ethnography designed to establish space for the voices of marginalised 
groups (Quantz \& O'Connor, 1988). Critical ethnography is described as an event in which multiple voices, especially marginalised voices, participate in a dialogue that moves towards the inclusion of all voices. Lather (1986b, p. 272) argued for, 'a more collaborative approach to critical inquiry ... to empower the researched, to build emancipatory theory, and to move toward the establishment of data credibility within praxis-oriented, advocacy research'. The meeting that I had with teachers was organised in a spirit of joint participation in the project of making classroom discourse and pedagogy more socially constituted. I explained to them the picture of their classrooms that had emerged from my observations:

a lot of teacher talk and a lot of student listening ... almost invariably closed and factual questions ... and predominantly total class instructional configurations around traditional activities - all in a virtually affectless environment ... They were implicitly teaching dependence upon authority, linear thinking, social apathy, passive involvement, and hands-off learning. (Sirotnik, 1983, p. 29)

I explained in terms which were as explicit and straightforward as possible how, instead of this approach, they could use transformative pedagogy where interactions between educators and students fostered collaborative rather than coercive relations of power (Apple \& King, 1983; Ball, 2000; Cummins, 1997; Freire, 1985, 1995; Shor, 1992) and promoted constructive developmental pedagogy which placed pupils at the centre of their learning. For example, I told teachers that they needed to ensure that pupils' home and family experiences were seen to be meaningful, valued, and appreciated in the classroom, not disparaged. The teachers equally needed to avoid making children feel that their everyday practices and cultural resources were inferior or second class. In order that children would be more confident and less docile, they were to be encouraged to feel sufficiently adequate and influential that they could determine the nature of the pedagogy in their classrooms.

The constructive developmental view of learning incorporates two major concepts: (1) that students construct knowledge by organising and making meaning of their experiences; and (2) that this construction takes place in the context of their evolving assumptions about knowledge itself and their own role in creating it (Magolda, 1999). I explained that constructive developmental pedagogy took a learning-centred approach that focusses on students' experiences as a context for introducing, working with, and constructing knowledge, rather than the traditional teaching-centred approach that focusses on knowledge acquisition and control.

After brief informal comments about the state of the school and resources, we shared the following observations:

- Classroom atmosphere was pleasant, but children were often rather too subdued.

- Lesson plans were always very brief and perhaps only understood by teachers themselves.

- Lesson content was often very much textbook based with little or no extension to children's everyday life.

- Lessons were usually devoid of the link between home and school even in topical everyday topics.

- Teachers appeared to avoid the use of the pupils' L1 even in the lower grades where they were expected to use it.

- Classroom practices left pupils subdued, alienated, and, on the whole, losers in the pedagogical struggle. 
Indeed, it was clear from the classroom observations that schooling functioned as a terrain of ongoing struggle over what will be accepted as legitimate knowledge and culture (Darder, 1991, cited in Darder, 1995). The need to engage critical pedagogy to address the concept of cultural politics was pertinent. Pupils' socio-cultural funds of knowledge and ways of knowing (Moll et al., 1990) were not integrated into the curriculum as a way of minimising their alienation. The foundation grades were disadvantaged by the insistent use of the L2, when in fact using L1 at appropriate levels enables bilingual children to learn L2 better (Cummins, 1984, 1986, 1997).

In the ensuing discussion, the teachers suggested that the subdued atmosphere often seen in class was because these were rural children who were generally not clever. Mrs Njanga, the senior woman, summed up the teachers' low expectation when she said:

Mr Muparari you should not think these children are the same as the clever urban children you are used to. Urban children are clever. They go to school by bus and ride bicycles in town giving way to motor vehicles. These children live with their old grandmothers and know very few clever things.

In relation to the use of L2 in lower grades, they pointed out that they were under an obligation to use English from as early in the children's schooling as possible to give them a head start, since ultimately it was their English, not their L1, that would determine their performance and success. The teachers also defended their scant lesson plans as a way of minimising paperwork. Otherwise, they largely appreciated the comments made and they promised to implement some of the new ideas that I had proposed wherever they could.

\section{Lessons conducted post intervention and feedback}

I have selected for analysis two lessons, both taught by student teachers subsequent to the feedback meeting. The choice of student teachers was based on the assumption that if students could demonstrate improved practice, qualified teachers could do even better. One of the lessons was an MT lesson (ChiShona) at Grade 5 and the other was a Grade 1 English oral lesson. The MT lesson was deliberately chosen to assess concurrently whether the previously subdued character of learners could be different where there was no language barrier.

\section{Extract 4:}

$<$ This extract is a Grade 5 (9-10-year-olds) ChiShona 'language structures' lesson taught by student teacher Mr Ngetani. A translation is given in italics immediately after the MT utterances. $>$

$<$ Topic: Zvemutauro.

Language structures

In the teacher's plan book, the following objectives were listed:

Vana vachakwanisa kushandisa mashoko okuvhunza zvikonzero.

Pupils will be able to use question tags for asking for reasons

Vachakwanisa kupindura mibvunzo vachipa zvikonzero

They will be able to answer questions by giving reasons. > 
$<$ Lesson development: Teacher introduced the lesson by presenting pupils with a scenario where children have been left at home alone by parents. $>$

T: Kana vabereki vachibva pamba kufamba rwendo kana kuenda kudoro vanosiya vati vana vachengete zvinhu. Vakawana zvinhu zvisina kumira zvakanaka vanobvunza mibvunzo. Ndaapi mashoko kana zvirevo zvinoshandiswa kubunza nokupindura mibvunzo yakadai?

When parents go away from home, for example, out to a beer party, on a journey, etc., they expect you to take care of things at home. If they find you have not done so, they will ask you to explain. They ask questions which demand an explanation. There are specific structures that are used to ask and answer these types of questions. Which are they?

P1: Uchizviitirei? Why do you do that?

P2: Nemhaka yei? For what good reason?

P3: Sei? How?

P4: Nei? Why?

P5: Nokuda kwei? For what reason?

P6: Ko, waitirei izvi? Why did you do this?

P7: Nemhaka yei usina kuita ichi? Why did you not do this?

P8: Sei warega izvi zvichidai iwe uripo? Why did you let this happen in your presence?

P9: Nokuda kwei waita izvi zvandakati handidi kuona?

Why did you do exactly what I have forbidden you from doing?

T: Mumapoka enyu ndinoda kuti mukurukure muchishandisa zvirevo izvi

In your groups I want you to discuss this topic using these structures.

$<$ Class breaks into groups, and after a few minutes, teacher says that the lesson is over and asks the class to pack their books before going out for break. $>$

The student teacher and I agreed that learners were active, relaxed, and enthusiastic during the lesson, including when presenting their group reports. Most group reports were based on real experiences and examples from real life. This made discussions in groups far more educationally constructive, as pupils were clearly more engaged with the task in hand. Pupils genuinely generated new and original knowledge and added new dimensions to the topic. One group, for instance, suggested that parents' behaviour was sometimes to blame for children's conduct and the consequent poor school performance. In marked contrast to the lessons where safe talk dominated, children raised issues of morality and responsibility in a language structures lesson as a result of the use of genuine content and the constructivist nature of the pedagogy employed. The teacher said that he was genuinely surprised with his pupils. It is through such activities that pupils are able to expand on their thinking, to justify or clarify their opinions, or to make connections to their own experiences (Abd-Kadir \& Hardman, 2007).

\section{Extract 5:}

This extract is a Grade 1 (5-6-year-olds) English oral lesson taught by student teacher Ms Kwevai. It illustrates the potency of using the MT and learners' socio-cultural experiences. Similar to the example which focussed on the use of between and among, this lesson was also based on grammar and, in particular, the use of the prepositions 'on', 'in', and 'under'. Although an English lesson, the teacher introduced the concepts (prepositions) in the students' MT, ChiShona, an interesting development following my comments on the use of the MT during the feedback meeting described above. Because the language policy says that L1 is the language of instruction from Grades 1 to 3, the teacher uses it even to teach English by translating into English and pupils answering in English.

$<$ The lesson started with an L1 jingle about early literacy: $>$ 
Pp: 'Bhi' rekutanga ratakadzidziswa: kutenderedza 'O';

Kugara kuti 'Dzi'! Kujamba kuti svetu! Uye kumira kuti tote!

The first letter of the alphabet that we were taught: writing out a circular ' $O$ ';

Sitting down like this. Jumping up into the sky like this! And, standing up at once like this!

$<$ This was repeated a second time and pupils enjoyed every minute of it as they acted out the activities. The lesson continued after the jingle: $>$

T: Sei tichidzidza kuverenga? Why do we learn to read?

P1: Kana usingaverengi hauoni yambiro mumugwagwa saka uri pangozi.

If you cannot read you might not see warnings on the road and will be in danger.

T: Motokari dzinofamba napai? Where do cars travel?

P: Motokari dzofamba nomumugwagwa. Cars travel along the roads

T: Kana muchidyira patafura ndiro munoisa pai? When you are eating on the table where do you place the plates?

Pp: Tinoisa pamusoro petafura. We place plates on top of the table.

T: Ko sadza munoisa pai? Where do you place food?

Pp: Sadza tinoisa mundiro. We place the food inside the plate.

T: Ko bhasikoro rinosendekwa pai? Where is the bicycle parked?

Pp: Bhasikoro rinosendekwa pasi pomuti. The bicycle is parked under the tree.

$<$ The teacher introduced the English target prepositions 'on', 'in', and 'under' using a ball to illustrate their meanings by placing it on the table, under the table, and in(side) the box $>$.

T: Ko, bhora ririkupi? < Translating: > Where is the ball?

P1: < Answering in English: $>$ The ball is on the table.

P2: The ball is under the table.

P3: The ball is in the box.

T: Kana muri kumba mukabvunzwa mwana ari kupi? $<$ Translating $>$ When you are at home and you are asked: 'Where is the baby; what do you say?'

T: Vangani venyu vane kumba kune vana vadoko? < Translating $>$ How many of you have parents with babies?

T: Vana vadoko vanovata pai kumusha? < Translating because this is an English lesson and pupils will be answering in English: $>$ Where do children sleep at home?

Pp: They sleep on the mat or on the bed.

$<$ Teacher now switches over to English only because the target English prepositions have been understood in the $\mathrm{L} 1$ context $>$.

T: Yes, the baby is sleeping on the mat. What about the ball?

Pp: The ball is on the table.

$<$ Teacher, showing class charts with pictures: $>$

T: Yes, look at these things found at home and say where they are usually kept. Write these out:

Where are the shoes?

Pp: The shoes are under the chair.

T: Do you put shoes under the chair at home? Yes under the chair and not on. Good!

$\mathrm{T}$ : Where are the goats?

Pp: The goats are under the tree.

$<$ Lesson then ended with the same L1 jingle now substituting the L1 prepositions with the learnt prepositions, 'in', 'on', and 'under' in English. $>$ 
This teacher rightly used the children's MT, ChiShona, in this Grade 1 English lesson. The teacher used children's MT first and went over the target structures again in English as a way of teaching. This appeared to improve not only the rapport but also the level of engagement, more so because the teacher exploited children's ability to express themselves more spontaneously. Asked to comment on her lesson afterwards, the teacher said that she had enjoyed the lesson more than any she could remember in recent times and that she had been surprised at the level of participation and confidence displayed by some of the pupils she previously considered passive and shy. She said that it was even more surprising that they were that free when there was a visitor among them.

\section{Discussion}

Before the intervention, the classroom norm was the well-practised or rehearsed patterns of procedure - labelled 'ritualized techniques' by Abd-Kadir and Hardman (2007), consisting of brief previous lesson recap, dysfunctional group work, limited report back, and individual written work based on textbook exercises or copying from the board. Often, pupils played a generally passive role and teachers, for their part, appeared to start from a very low expectation of pupil ability, praising pupils disproportionately for their contributions and perceived good (or docile) behaviour. In much of the earlier classroom interactions observed, consistent with the transmission model, the teacher's role was to prepare and transmit information to learners and the learners' role was to receive, store, and act upon this information. The expectation was that learners would commit the facts and procedures to memory and strive to become fluent and precise.

Extracts from lessons before the intervention, unlike those after, illustrate the negative aspects of behaviourist safe talk (Hornberger \& Chick, 2001) in the context of transmission models of teaching (Tishman et al., 1992) that run completely contrary to critical pedagogy. The extracts illustrate how habits of thought, reading, writing, and speaking remain at surface meaning and first impression levels (Shor, 1992, p. 129). The social world of learners and their home literacy practices are systematically excluded from the classroom practices. The use of the second language and its symbolic violence (Bourdieu, 1991) was apparently one of the main reasons for this pedagogical defect and remains one of the biggest barriers to effective teaching and learning in these classrooms. Teachers often stuck to what was in the textbook and thus avoided soliciting any real pupil experience, even in relation to commonplace topics. The larger parts of the lessons focussed on the narrow prescriptive content (learning as product) instead of on the meaning-making process. In an environment where parents battled with basic issues of survival, a safe talk and behaviourist-based transmission model of pedagogy reproduced inequality, alienation, and underachievement.

The extracts from those lessons taught after the intervention illustrated that the process of transforming behaviourist-based pedagogy for constructive developmental pedagogy is apparently very important. The rural and the disadvantaged learners need to have their socio-cultural practices (e.g. language, music, and dance) validated as worthwhile in the school domain before they can be fully integrated to become empowering critical discourses. Children need to be afforded the chance to start from their own familiar home setting with a curriculum and a pedagogy that recognise their cultural heritage. They need to be allowed to generate their own ideas and find their own voices (Magolda, 1999). Writing about the need for children to start from their own culture if they were to develop an integrated perspective on literacy, Gbado (2008, p. 1) highlighted the importance of identity: 
Every child has the right to bathe in his own culture, to be nourished by his mother culture before being fed by the culture of others ... Children must be made conscious of their identity so that they can grow from their cultural roots. They must be themselves so that they can be enriched by others better, so that they can enrich others better.

\section{Conclusion}

My experience at Chitubu Primary School, a typical rural Zimbabwean classroom, demonstrates how classroom-based reform initiatives can become a catalyst for the improvement of general pedagogical practice in the system as a whole. Teachers need to value and promote the place of learners' social and cultural practices in the school curriculum in order to promote children's integration and avoid alienation. The momentum created by the validation of learner cultural practices has to be harnessed in order to create a new constructivist culture in the classroom. As Magolda (1999) said, teachers must create conditions within which students are validated as knowers (sic) rather than as passive receptacles into which experts pour knowledge. Pedagogical practices must situate learning in students' own lives, drawing on their previous experiences and creating new ones, rather than presenting knowledge as detached and free-floating. Teachers must collaborate with students in defining and understanding learning as mutually constructed meaning. The rural African classroom, therefore, remains an important arena for the ongoing struggle over what will be accepted as legitimate knowledge, culture, and pedagogy. An urgent need remains to embrace critical pedagogy by legitimising the cultural practices of the learners and challenging the current social reality where pedagogies often alienate the rural and underprivileged learners.

\section{References}

Abd-Kadir, J., \& Hardman, F. (2007). The discourse of whole class teaching: A comparative study of Kenyan and Nigerian primary English lessons. Language and Education, 21(1), 1-15.

Agar, M.H. (1996). The professional stranger: An informal introduction to ethnography. San Diego, CA: Academic Press.

Apple, M., \& King, N. (1983). What do schools teach? In H. Giroux \& D. Purple (Eds.), The hidden curriculum and moral education (pp. 82-99). Berkeley, CA: McCutchan Publishing.

$\mathrm{Au}, \mathrm{K}$. (1993). Literacy instruction in multicultural settings. Fort Worth, TX: Harcourt Brace.

Ball, A.F. (2000). Empowering pedagogies that enhance the learning of multicultural students. Teachers College Record, 102(6), 1006-1034.

Bennett, C.I. (1999). Comprehensive multicultural education: Theory and practice (4th ed.). Boston, MA: Allyn and Bacon.

Berger, L. (2001). Inside out: Narrative autoethnography as a path toward rapport. Qualitative Inquiry, 7(4), 504-518.

Bloch, C. (2005). Building bridges between oral and written language: Facilitating reading opportunities for children in Africa. Cape Town: PRAESA.

Bourdieu, P. (1991). Language and symbolic power. Harvard, MA: Harvard University Press.

Brock-Utne, B. (2001). Education for all - in whose language? Oxford Review of Education, 27(1), $115-134$.

Brock-Utne, B., \& Alidou, H. (2005). Experience II - active students - learning through a language they master. In ADEA/GTZ/Commonwealth Secretariat/UIE (2005), Optimizing learning and education in Africa - the language factor. A stock-taking research on mother tongue and bilingual education in sub-Saharan Africa. Retrieved from http://www.adeanet.org/biennial-2006/ doc/document/B3_1_MTBLE_en.pdf

Brock-Utne, B., \& Hopson, R. (2005). Languages of instruction for African emancipation: Focus on postcolonial contexts and considerations. Ann Arbor: Michigan State University Press.

Carspecken, P.F. (1995). Critical ethnography in educational research: A theoretical and practical guide. London: Routledge. 
Carspecken, P.F., \& Apple, M. (1992). Critical qualitative research: Theory methodology and practice. In M.D. Lecompte, W.L. Milroy, \& J. Preissle (Eds.), The handbook of qualitative research in education (pp. 507-553). San Diego, CA: Academic Press.

Chick, J.K. (1996). Safe-talk: Collusion in apartheid education. In H. Coleman (Ed.), Society and the language classroom (pp. 21-39). Cambridge: Cambridge University Press.

Cummins, J. (1984). Bilingualism and special education: Issues in assessment and pedagogy. Clevedon: Multilingual Matters.

Cummins, J. (1986). Empowering minority students: A framework for intervention. Harvard Educational Review, 56(1), 18-36.

Cummins, J. (1997). Introduction: Bilingual education. In J. Cummins \& D. Corson (Eds.), International encyclopedia of language and education (Vol. 5, pp. xi-xiv). Dordrecht: Kluwer Academic.

Cummins, J., \& Sayers, D. (1995). Brave new schools: Challenging cultural illiteracy through global learning networks. New York, NY: St. Martins' Press.

Darder, A. (1995). Buscando America: The contributions of critical Latino educators to the academic development and empowerment of Latino students in the US. In C.E. Sleeter \& P.L. McLaren (Eds.), Multicultural education, critical pedagogy and the politics of difference (pp. 319-347). New York, NY: SUNY Press.

Dei, G., \& Asgharzadeh, A. (2005). Language, education and development: Case studies from southern contexts. Language and Education, 17(6), 421-449.

Edwards, V. (1998). The power of Babel: Teaching and learning in multilingual classrooms. London: Trentham Books.

Ellis, C., \& Bochner, A.P. (2000). Autoethnography, personal narrative, reflexivity: Researcher as subject. In N. Denzin \& Y. Lincoln (Eds.), Handbook of qualitative research (2nd ed., pp. 733-768). Thousand Oaks, CA: Sage.

Fillmore, L.W., \& Snow, C.E. (2000). What teachers need to know about language? Centre for Applied Linguistics, August 23. Retrieved August 26, 2011, from http://citeseerx.ist.psu.edu/ viewdoc/download?doi=10.1.1.92.9117\&rep=rep1\&type=pdf

Freire, P. (1985). Reading the world and reading the word: An interview with Paulo Freire. Language Arts, 62(1), 15-21.

Freire, P. (1995). Pedagogy of hope: Reviving pedagogy of the oppressed. New York, NY: Continuum.

Freire, P. (2006). Pedagogy of the oppressed (M.B. Ramos, Trans.). New York, NY: Continuum. (Original work published 1970).

Freire, P., \& Macedo, D. (1987). Literacy: Reading the word and the world. New York, NY: Bergin and Garvey.

Gbado, L.B. (2008, August 10-14). What challenges has your library faced? How did you respond? The Benin Case. Presented at the World Library and Information Congress: 74th IFLA Conference and Council, Quebec, Canada.

Gee, J.P. (1996). On mobots and classrooms: The converging languages of the new capitalism and schooling. Organization, 3(3), 385-407.

Gonzalez, N., Moll, L., \& Amanti, C. (Eds.). (2005). Funds of knowledge: Theorizing practices in households, communities and classrooms. Mahwah, NJ: Lawrence Erlbaum Associates.

Gonzalez, N., Moll, L.C., Floyd-Tenery, M., Rivera, A., Rendon, P., Gonzales, R., \& Amanti, C. (1993). Funds of knowledge: Learning from language minority households. Washington, DC: National Center for Research on Cultural Diversity and Second Language Learning.

Greenberg, J.B. (1989, April). Funds of knowledge: Historical constitution, social distribution and transmission. Paper presented at the Annual Meeting of the Society for Applied Anthropology, Santa Fe, MN.

Gutierrez, C., Larson, J., \& Kreuter, B. (1995). Cultural tensions in the scripted classroom: The value of the subjugated perspective. Urban Education, 29(4), 410-442.

Hornberger, H., \& Chick, J.K. (2001). Co-Constructing school safe time: Safe talk practices in Peruvian and South African classrooms. In M. Martin-Jones \& M. Heller (Eds.), Voices of authority: Education and linguistic difference (pp. 31-56). London: Ablex.

Irvine, J.J., \& Armento, B.J. (Eds.). (2000). Culturally responsive lesson planning. Boston, MA: McGraw-Hill.

Lankshear, C., Gee, J.P., Knobel, M., \& Searle, C. (1997). Changing literacies. Buckingham: Open University Press. 
Lather, P. (1986a). Issues of validity in openly ideological research: Between a rock and a soft place. Interchange, 17(4), 63-84.

Lather, P. (1986b). Research as praxis. Harvard Educational Review, 56(3), 257-277.

Magolda, M.B. (1999). Creating contexts for learning and self-authorship: Constructive developmental pedagogy. Nashville, TN: Vanderbilt University Press.

Moll, L.C., Amanti, C., Neff, D., \& González, N. (1992). Funds of knowledge for teaching: Using a qualitative approach to connect homes and classrooms. Theory into Practice, 31(2), 132-141.

Moll, L.C., Velez-Ibanez, C., Greenberg, J., Whitmore, K., Saavedra, E., Dworin, J., \& Andrade, R. (1990). Community knowledge and classroom practice: Combining resources for literacy instruction. Tucson, AZ: University of Arizona College of Education and Bureau of Applied Research in Anthropology.

Molteno, F. (1984). The historical foundations of the schooling of black South Africans. In P. Kallaway (Ed.), Apartheid and education: The education of black South Africans (pp. 45-107). Johannesburg: Ravan Press.

Newfield, D., \& Stein, P. (2000). The multiliteracies project: South African teachers respond. In B. Cope \& M. Kalantizis (Eds.), Multiliteracies: Literacy learning and the design of social futures (pp. 292-310). South Yarra: Macmillan.

New London Group. (1996). A pedagogy of multiliteracies: Designing social futures. Harvard Educational Review, 66(1), 60-92.

Probyn, M.J. (2001). Teacher's voices: Teachers' reflections on learning and teaching through the medium of English as a second language. International Journal of Bilingual Education and Bilingualism, 4(4), 249-266.

Quantz, R.A., \& O'Connor, T.W. (1988). Writing critical ethnography: Dialogue, multivoicedness, and carnival in cultural texts. Educational Theory, 38(1), 95-109.

Reed-Danahay, D.E. (Ed.). (1997). Auto/ethnography: Rewriting the self and the social. New York, NY: Berg.

Scheerens, J. (2000). Improving school effectiveness: Fundamentals of education planning. Paris: UNESCO/IIEP.

Shor, I. (1992). Empowering education: Critical teaching for social change. Portsmouth, NH: Heinemann.

Simon, R.I., \& Dippo, D. (1986). On critical ethnographic work. Anthropology \& Education Quarterly, 17(4), 195-202.

Sirotnik, K.A. (1983). What you see is what you get - consistency, persistency, and mediocrity in classrooms. Harvard Educational Review, 53(1), 16-31.

Skutnabb-Kangas, T. (1981). Bilingualism or not: The education of minorities. Clevedon: Multilingual Matters.

Thomas, J. (1993). Doing critical ethnography. Newbury Park, CA: Sage.

Tishman, S., Jay, E., \& Perkins, D.N. (1992). Teaching thinking dispositions: From transmission to enculturation. Theory into Practice, 32(3), 147-153.

University of Zimbabwe. (2002). Zimbabwe literacy norms project. Harare: University of Zimbabwe.

Velez-Ibanez, C. (1989, April). Transmission and patterning of funds of knowledge: Shaping and emergence of confianza in US Mexican children. Paper presented at the Annual Meeting of the Society for Applied Anthropology, Santa Fe, NM.

Verspoor, A.M. (Ed.). (2003). The challenge of learning: Improving the quality of basic education in sub-Saharan Africa. Paris: Association for the Development of Education in Africa.

Williams, J.D., \& Snipper, G.C. (1990). Literacy and bilingualism. New York, NY: Longman.

Willis, A. (1995). Reading the world of school literacy: Contextualizing the experience of a young African American male. Harvard Educational Review, 65(1), 30-49. 